\title{
Some Deviations of Form: A Little Essay on Psychoanalysis, Art and Aesthetics
}

\author{
Gustavo Henrique Dionisio \\ Clinical Psychology Department, São Paulo State University (UNESP), EBEP-SP, Assis, Brazil \\ Email: gustavohdionisio@gmail.com
}

Received 5 September 2014; revised 30 September 2014; accepted 12 October 2014

Copyright (C) 2014 by author and Scientific Research Publishing Inc.

This work is licensed under the Creative Commons Attribution International License (CC BY). http://creativecommons.org/licenses/by/4.0/

\section{(c) (i) Open Access}

\begin{abstract}
This work intends to investigate the use of psychoanalytical theory within the aesthetic and critical contemporary art field. To this purpose, it focuses on two philosophers who have become significant in our time: the art critic Hal Foster and the art historian Georges Didi-Huberman. This study aims to show how far the concepts generated in psychoanalytic praxis allowed interpretations that disrupt the traditional aesthetics field. This type of analysis is possible once we abandon the paradigm of "applied psychoanalysis", which is still current in non-clinical setting. Finally, the proposal wants to argue that the category of the amorphous may clarify certain aesthetic experiences that range from the modernity of art through postmodernity.
\end{abstract}

\section{Keywords}

Psychoanalysis, Aesthetics, Figurability, Deferred Action, Amorphous

\section{Reading Images: Art and Psychoanalysis}

It is not an unknown fact that psychoanalysis, art and aesthetics have their mutual influences; but, as we widely understand, the relationship between these fields does mean a very significant chapter in the history of Freudian ideas. In one or another hand, psychoanalysis, for instance, has always searched, in the art field and its critical fortune, a certain number of tools to understand the psychological phenomena. At the international art scene, theorists, art historians and critics, in their turn, never ceased to introduce psychoanalytical concepts into consideration, and especially in this time we are living in; this behavior occurs even when that ownership is immersed in a series of discursive resistances, that by itself could justify new researches to be done.

To Freud, for instance, is well known how the aesthetic experience was absolutely essential. Otherwise, it is necessary to emphasize that the studies made for the journal Imago were quite limited, certainly because of its focusing on the use of image content in order to "prove” some analytical theories (Freud, 1996a, 1996b, 1996c, 
1996d). This kind of interpretation occurs in Delusions and dreams of Jensen's Gradiva, Dostoyevsky and parricide, Creative writers and daydreaming, etc. culminating in a method of reading images that had become the princeps way among the Freudian interpretation-in this case, certainly related to art works: that means the article he wrote about Leonardo da Vinci and one memory of his childhood. This study was transformed into a kind of Mecca in which psychopathological theories gain their term, especially in regard of a psychological diagnosis. As we know, the homosexuality and narcissism of Leonardo will be exposed and explained there, almost without any mediation, i.e., always by means of his paintings, what have encourage interpretations such as "if someone paints like this, he's schizophrenic, like that, neurotic", and so on (Van Gogh is, perhaps, the most celebrated artist in this context).

But the text about Michelangelo's Moses, from 1914, shows us in this matter, however, a very interesting essay, another point of view. It is here that Freud will take into account-and this information becomes, indeed, a crucial piece for this study - the importance of the art spectator and the affluence of his aesthetic perception. In other words, the article reveals one Freud that leaves himself to the emotions entailed in the act of contemplation. Creating, indirectly, a new problem of research for the analyst, Freud chooses the emotional reaction of the viewer as the main subject of his investigation, that is to say, the subject here is what he would feel himself in front of the sculpture. According to his reading, the whole intention of the artist is always transmitted through a solution that he can give to the amount of emotions, representations, displacements etc., making of them, ultimately, works of art.

Thus, the art work reaches its target, because it was able to bring to the surface the top of an iceberg whose enigmatic remaining content every artistic work has the merit to announce. In other words, here we see the moment that our psychoanalyst, who wanted to be a writer, corrected himself...and just in time, we could also add.

So, what can we say about this? From one study to another, we find a paradigm shift in the passage of an applied psychoanalysis to a kind of implied psychoanalysis, i.e., "branched" in the work of art, as indicated by Frayze-Pereira (2005), a Brazilian psychoanalyst. In short terms, we could define the so called applied psychoanalysis as a psychoanalytical "method" that aims to interpret any data (non-clinical, in special) with the psychoanalytical theory. The main problem is "its results", saying in a more direct way: in doing so, applying its corpus, this theory does not respect the particular properties of the subject (for example sociological, anthropological, and so on), or whether there is or isn't any kind of demand of that theory; in most cases, it reveals to be as positivist as theoretic violent regard to the studied subject.

The implied analysis, in the other way, seems to be a psychoanalytical approach more close to Lacan's famous proposition of 1967, which one the French psychoanalyst calls "psychoanalysis in intension" in order to criticize the idea of a "extended" psychoanalysis. In different words, as we would like to affirm, perhaps it is something alike as it was described by Serge Leclaire's (Lacan most famous disciple, some people should agree) in his book Psychanalyser (Leclaire, 2007). There he writes:

"One can see, then, the double exigency imposed to the psychoanalyst. In one hand, it is necessary for him to keep one reference system, a theory that guarantees an organization of the material amount he takes without a previous discrimination. In the other hand, he must refuse, precisely, every reference system in terms that this adhesion to a theoretical ensemble takes him necessarily, whether or not, to treat in a privileged way certain elements (p. 22, in a free translation)".

In this terms, and strictly speaking, the psychoanalytic theory that wants to apply its method to any kind of subject seems to refer to a great need of reading the artistic creation, that is, a certain psychoanalysis which doesn't intend to engage with the aesthetic reception problems (and here reception underlined mostly because of methodological reasons). Affiliated to the biographic interpretation key, this so called applied psychoanalysis will inevitably tend to nosography and psychopathology. Reading the earliest texts of Ernst Kris, like Psychoanalytical explorations on art (Kris, 2000), and the essays on art of the ego-psychologists, it's enough to realize it really well (Dionisio, 2012).

But "imply yourself" means, moreover, that the investigator does not exclude his subjective structures from the field he is dealing with. The idea of a whole, that is, a relational structure, we could say, is here essential. Involved, as such, with the work of art, the psychoanalyst should expect that the reading to be done will certainly become one risky activity, "because the interpreter is free on one side just as connected into the other, and it can happen that his/her findings will affect the relationship with his/her own unconscious” (Frayze-Pereira, 2005: p. 74).

In that perspective, on the other hand, the analysis is committed to be derived from art or "imbedded" on it, 
especially because its interpretation is not just a simple way to apply the analytical method to an external matter. Since it is not only an abstract model that wants to frame, not without violence, the artistic object to its theoretical-conceptual demands, it raises the possibility that this interpretation can be congenial to the form itself, behold its highest risks. Perhaps Lacan, in his own way, have said it yet: instead of the "extended" one, let us use the psychoanalysis in intension, he said in the proposition early mentioned.

\section{Aesthetical Thinking and Psychoanalytical Investigation}

In the particular circuit of aesthetic research, this sort of implied interpretation does not cease to be present. According to a previous research conducted recently by me (in 2010, at the São Paulo Public University-USP), we feel able to highlight two significant characters in this context: they are scholars such as the art critic Hal Foster, professor at Princeton University and co-editor of the October journal, so important in this scenario; and the second one is the art historian and philosopher Georges Didi-Huberman, professor at the École des Hautes Études en Science Sociales, in Paris.

Dealing with aesthetic issues that ranges from modern to postmodern era, both of them-who are disciples of Rosalind Krauss and Daniel Arasse, respectively - try to import certain concepts from the psychoanalytical repertoire, and one can say they do it in a very singular way: in their writings, we see concepts as trauma, posterity or deferred action (Nachträglichkeit) and repetition, on the case of Foster in his The return of the real (Foster, 1996), as well as a theory about the gaze (regard), on the basis of a systemic structure that creates categories as “incarnate”-incarnat-, “screen/cloth”-pan-, “skin”-peau-, and “detail”—détail, in a certain lacanian way, in my opinion, as we will see hereafter, and other notions like symptom and representability, mostly used by DidiHuberman's thinking in La peinture incarnée (Didi-Huberman, 1984), Devant l'image (Didi-Huberman, 1990), Ce que nous voyons, ce que nous regarde (Didi-Huberman, 1997).

The outline of this work of mine, which is to assemble those authors in a sequence, merits on producing a "unit of meaning" that encompasses certain ways through which passes much of the contemporary theory of art criticism. And in order to do so — that's the main thesis the author want to support here-we need to say that the reference those authors make towards the psychoanalytical repertory, and in both cases, is kind of a sine qua non condition, in different words, it is almost enforceable, mandatory. In my opinion they compose, indeed, the two sides of the same coin: on one hand, we have Didi-Huberman building a very complex theory of art history that crosses frontiers, coming to art theory. Meanwhile, in the other hand, we see one Hal Foster working directly over the latest contemporary movements, mostly dedicated to photography, video or painting, and offering a reflection that does not fail to cover the minutiae of a detailed critical discussion.

It's impossible to summarize such complex theories now and here ${ }^{1}$, of course, but one can feel a little bit of its taste. Starting from questions involved with the real (Lacan) and the concept of repetition, for instance, as presenting new problems towards the uncanny, as we would suggest, both authors flirt with the analysis of the figurability as an illustration of the visual paradigm. These are the main concepts imported, and this is done in a very appropriately manner-in my opinion-by our critics. Those categories will be discussed, in both of them, from the perspective of a sharp reflection about art. Flesh and blood (the "incarnate"), canvas and skin, trauma and repetition: aren't we dealing with the most primary processes of the mind? How could be set the idea of an unconscious without aesthetic categories as those?

Nevertheless, one linkage between these authors cannot be verified by a simple back-and-forth. Looking more closely, the convergence between those issues leads us to certain problems already questioned by Freud, especially on his Beyond the Pleasure Principle, one of his most controversial essays.

Analyzing images ranging from the abject art of the 1990's, or the pop art from the 60's (Foster) towards the minimalism movement; or even discussing the modern painting of Frenhofer (Le Chef d'oeuvre inconnue from Balzac, as in the case of Didi-Huberman), both of our critics are dealing with issues which are addressed, strictly speaking, to repetition compulsion and death drive.

And now, thinking more closely at the postmodern moment of art, which would be the psychoanalysis that could support the interpretations they desired? In other words, in which kind of psychoanalysis these art critics rely?

At first, we shall say that the influence of Lacan is quite decisive-as anyone could see through this essay. As we should see here, for the "good listener, half of a word is enough": the notion of a "quadrature", form Didi-

${ }^{1}$ For a more advanced questions, I suggest the reader to search for my book (Dionisio, 2012).

${ }^{2}$ In a really "problematic" free translation. It is related to some mathematical structures of four terms, like in Lacan's discourses, for example (with $\mathrm{S}_{1}, \mathrm{~S}_{2}, \mathrm{a}, \$$ ). 
Huberman writings, has its origin right there, it is almost like that theory would be "the younger sister" of the famous "quadripodes", developed by the French master during his seminars. As so, the recovery of concepts like symptom - which in the aesthetic context we think it is more closer to the category of desire, in a more suggesting way, taking some of the Serge Leclaire's ideas from his work earlier mentioned—or concepts such as drive and gaze seems to be a clear reference to Lacan's Four Fundamental Concepts of Psychoanalysis, which is, perhaps, the most aesthetic seminar once offered by him (Lacan, 1998).

Secondly, however, we believe that this connection can still be spread wider if we access the analyses made by Green (1994), at first, and César and Sára Botella (2007), just nearby, who both suggest, in their studies, some advances on the theory of psychic representation.

Let us look more closely.

Actually, if the problem of representation has been overcome, inside of the aesthetic field-the current number of attacks towards the concept of sublimation is, very certainly, a great symptom of this crisis-what can one think about it, however, when it comes to the psychic reality? What are we speaking when discuss figurability - a concept which is often accessed by Didi-Huberman — or the death drive - to which Foster refers repeatedly-without a support given by the category of representation?

It is betting on this aim that those analysts aspired to build a clinical-theoretical corpus, a structure in which can be included, indirectly, limits and conquers from the relation between "psychoanalysis and art", subject once selected by me.

One cannot reach, in Foster and Didi-Huberman, any quotes from Andrè Green or César and Sára Botella. In my point of view, these theories are, nevertheless, complementary. Somehow, all the "gaps" to be examined in that critic analytical thinking could be traced back to the absence of a clinical experience itself. In other words, what Foster and Didi-Huberman "miss" is kind of a real entrance in the "state of session", as say one definition developed by the Botella couple: the concreteness of the "session itself", required by any psychoanalytical procedure (or adventure).

But at the reception that Foster and Didi-Huberman works address to art, we want to say that lies, in there, a real regredient ${ }^{3}$, retrogressive movement (Botella, 2007), an operation that seeks to rewrite the way that leads from the form to the amorphous that have been there before, as the author wants to affirm it, here (i.e., the abject, the deformed, the in-form, if we want, which are a sort of half-way towards the form in itself). Dealing with non-representable phenomena, their reflection creates an encounter with the primary dimension of the psychic reality.

However, these regredient images, as suggested by the American historian and elaborated by the French theorist, would be examples of a "metacritic" tout court: in itself, they contain one large springboard for a discussion on the implied reflections on art and psychoanalysis. Both have entered a field in which is possible to access the drive in its relationship with "the hallucinatory, the perceptive, the representable and the inscriptive" (Botella, 2007: p. 238). Certainly, here the category of hallucinatory is not restricted only to one psychological position - the psychosis, in this case-but it claims the broader phenomenon of perception, an experience that everyone has to go through.

Regarding to more theoretical aspects, i.e. the relationship between the art receiver and the work of art, these two positions can be expressed as antipodes of wild psychoanalysis. Each one access the psychoanalytical theory in his way, taking what it seems most appropriate to the (art) object to be investigated.

In analytical terms, on the other hand, Botella points, today, the existence of a "simultaneous confrontation" between different mental processes, in front of which contemporary psychoanalysis and analysts are compelled to say something: if our causality can be abstained from linear temporality, then a real simultaneity "between dream and day thinking; between hallucinatory and memory; between negative childhood trauma and work of representability", shall have itself one psychic reality, that is, a third reality between the ones of "representational dominance and procedural predominance" (Botella, 2007: pp. 235-238); thus, between the representative and the hallucinatory, in other way.

It is really surprising that this notion of a "regredience" makes much sense at the moment: in a period that comes from the 1980's to now, one can see at least three versions of this operation:

1) At first, some species of "genital pornography", mostly evident in works such as some Cindy Sherman and Jeff Koons photographs. In their work one can see interventions that comes from bizarre arranged dolls (Sherman) to the artist (Koons) illustrating himself. Koons, for instance, was actually married with a well-known porn

\footnotetext{
${ }^{3}$ Originally, the Botella couple uses the term "régrediént".
} 
star (See Figure 1-Cindy Sherman, Untitled \#258, 1992, and Figure 2-Jeff Koons, Made in heaven, 1990).

2) Secondly, a certain kind of "eschatological anality”, closely watched in works like Andres Serrano's Piss Christ where the spectator shall contemplate a crucifix inside a urine solution, and Piero Manzoni's Artists Shit (Figure 4), which is self-explicative, for example (Figure 3-Andres Serrano, Piss Christ, 1987, and Figure 4-Piero Manzoni, Merda d'artista, 1961).

3) And finally, a particular way in which we can see some of a "voracious orality", certainly originated in the whole tradition of vampirism, as we can watch nowadays at any movie theater on the corner. And we could even add here some of the strongest paintings made by the British artist Damien Hirst, who plays with this orality with presenting full colored pills (See Figure 5, from this classic Nosferatu movie, and Figure 6, Damien Hirst's The tears of Jesus, created between 2003 and 2005).

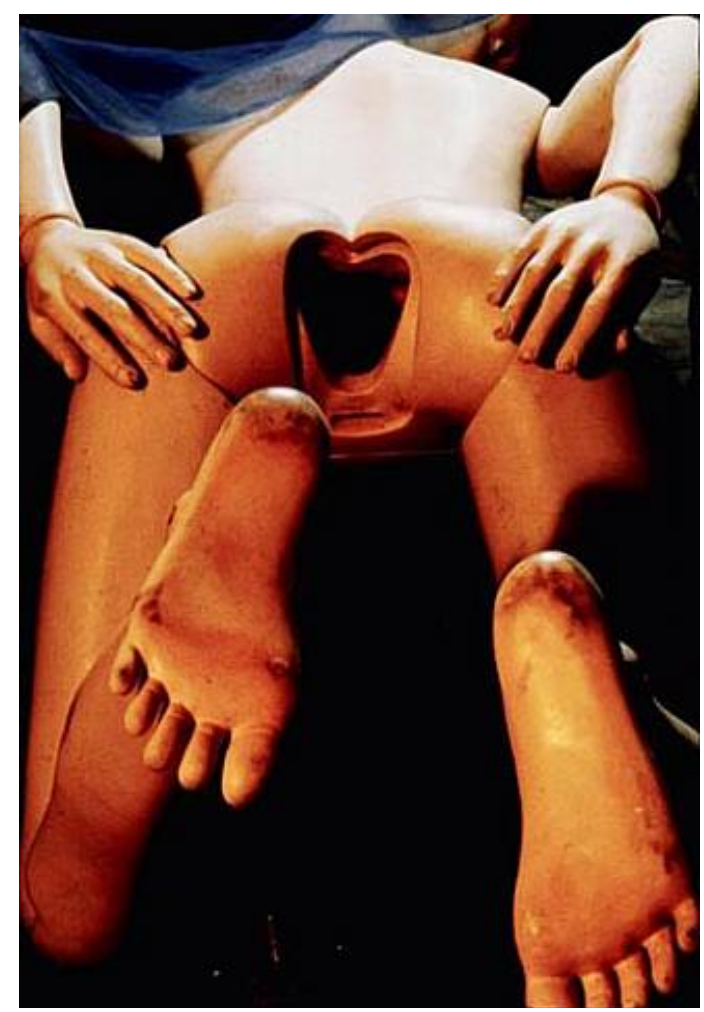

Figure 1. Cindy Sherman, Untitled \#258, 1992.

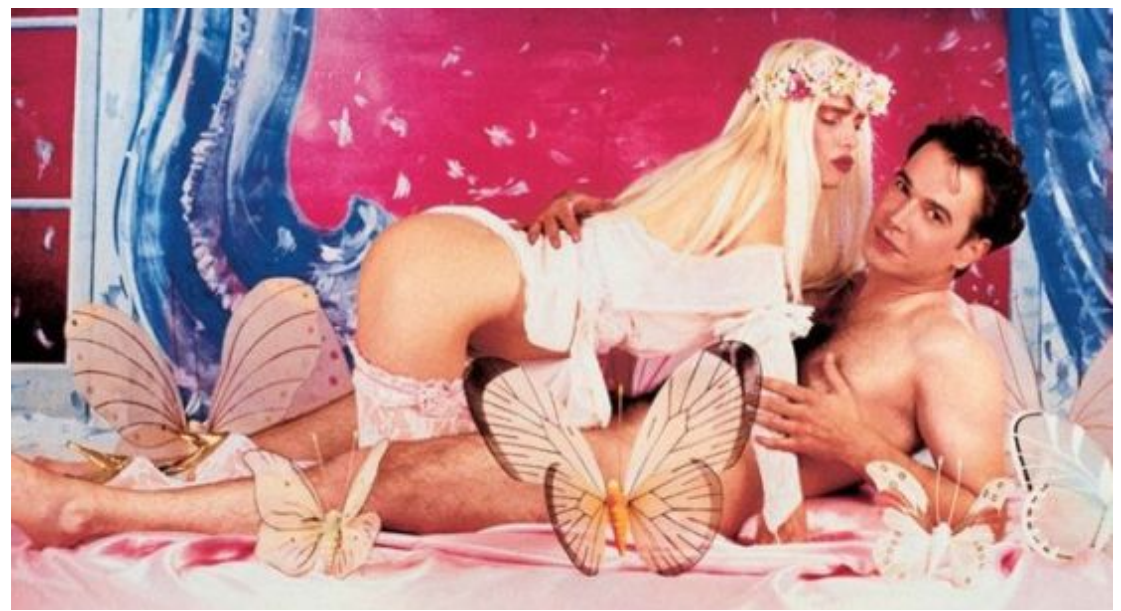

Figure 2. Jeff Koons, Made in heaven, 1990. 


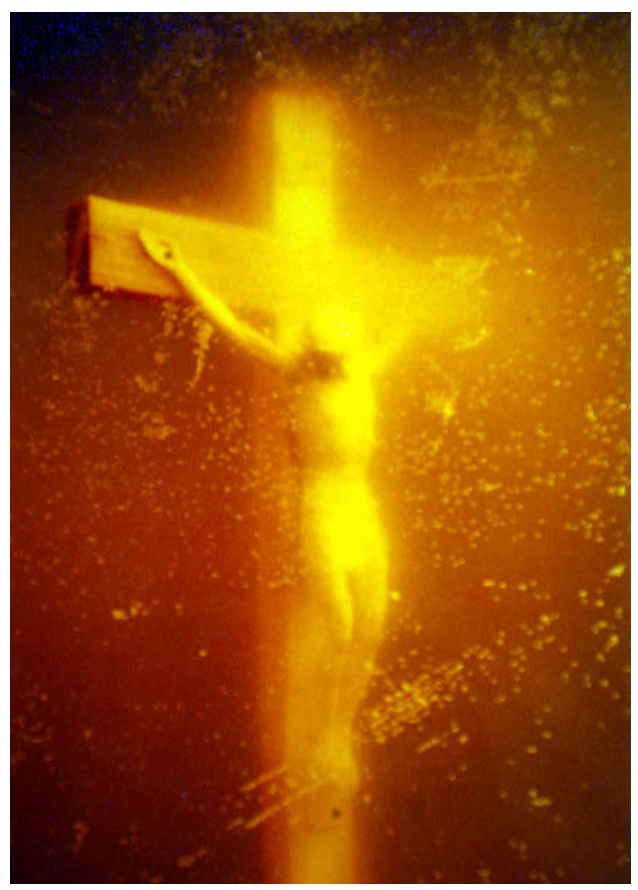

Figure 3. Andres Serrano, Piss Christ, 1987.

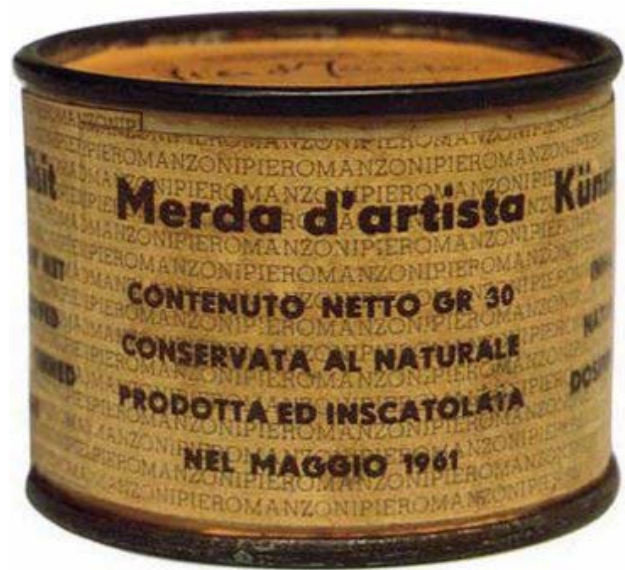

Figure 4. Piero Manzoni, Merda d'artista (Artist's shit), 1961.

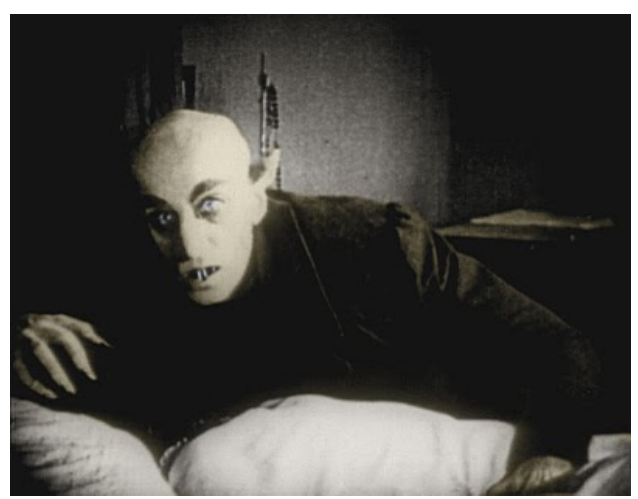

Figure 5. Detail of Nosferatu. 


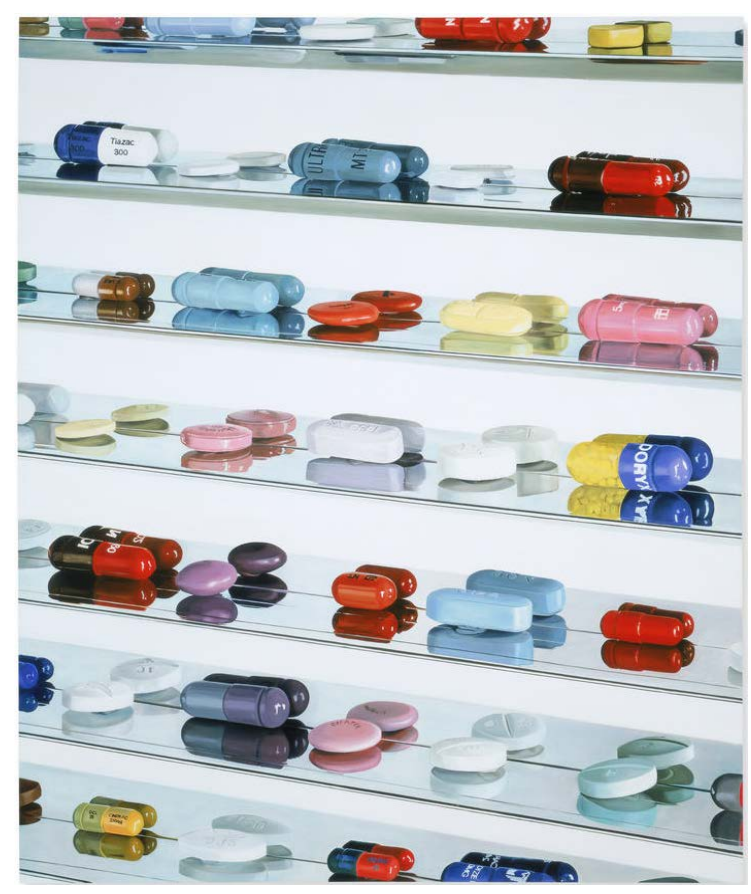

Figure 6. Damien Hirst, The tears of Jesus, 2003-5.

\section{Form, Non-Form}

To summarize, we suggest that this whole activity of art reading, which revolves around negative categories, can be summarized in a crucial question: how we can "find a way out for the desire to live and love", would ask André Green, in "face of the destruction that threatens to anything”? (Green, 1994: p. 249). An absolute omnipotent satisfaction or one kind of "sublimate" resignation? In a metapsychological language, it is as if Foster and Didi-Huberman were dealing with the remains of used images (as Lacan, by the way, would certainly suggest), as used as psychic objects. They resist, indeed, precisely because they stay so close to the destructive disposition of the death drive, but only under the condition of the reverse of the amorphous form-how the author should finally defend here-an operation that falls under a process of intense inversions. When we talk about this amorphous we refer to the unbinding processes involved to that death drive dynamics, of course.

"Poietic execution", "aesthetics of desire" or of "refusal" would be other designation which seems to legitimize this kind of critical reception, as proposed by a philosopher like Murielle Gagnebin, for example: "Linked on repetition and recollection, it releases from the 'chimera' or the 'monstrous' a creative potential that aid us to interpret”, she says. And in according to the French master, Gagnebin also suggests that criticism should be an intense transformation of the "intoxicating powers of the trompe-l'oeil in a real organic of dompte-regard" (Gagnebin, 1994: p. 261). After all, for her, all these frightening contemporary images are nothing but a mean by which artists can say no.

But we cannot fully share her opinion. After this whole discussion, one could not conclude that under this relationship between psychoanalysis and aesthetics lives a latent potentiality of resistance, in front of the destruction? If both remain - art and psychoanalysis — it is because the object has its own strength to survive, as Winnicott would say, despite all the destructive strategies. And we believe that Lacan, for instance, wouldn't diverge (lots of, at least!) from this opinion. And it seems that this confrontation is not only one certain negativity, but a process of co-creation, one adventure to get ourselves lost in the gaze of the other. In a few words, this is a process meant to be addressed not only to psychoanalysis-this is what my latest studies sought to demonstrate-but also to the aesthetic thinking, which in fact has been done simultaneously, as we think we could demonstrate.

\section{References}

Botella, C. (2007). The Work of Psychic Figurability: Mental States without Representation. Paris: In Press. 
Didi-Huberman, G. (1984). The Embodied Painting. Paris: Les Editions de Minuit.

Didi-Huberman, G. (1990). Confronting Images: Questioning the Ends of a Certain History of Art. Paris: Les Editions de Minuit.

Didi-Huberman, G. (1997). What We See Looks Back at Us. Paris: Les Editions de Minuit.

Dionisio, G. H. (2012). You Shall Open Your Eyes: Psychoanalysis and Aesthetic Thinking Today. São Paulo: Annablume/ Fapesp.

Foster, H. (1996). The Return of the Real: The Avant-Garde at The end of the Century. Cambridge: MIT Press.

Frayze-Pereira, J. A. (2005). Art, Pain. Disquiet Questions between Aesthetics and Psychoanalysis. Cotia, SP: Ateliê Editorial.

Freud, S. (1996a). A Case of Hysteria, Three Essays on Sexuality and Other Works (1901-1905). In: The Standard Edition of the Complete Psychological Works of Sigmund Freud (Vol. VII), Rio de Janeiro: Imago.

Freud, S. (1996b). Five Lectures on Psycho-Analysis, Leonardo and Other Works (1910). In: The Standard Edition of the Complete Psychological Works of Sigmund Freud (Vol. XI). Rio de Janeiro: Imago.

Freud, S. (1996c). Totem and Taboo and Other Works (1914). In: The Standard Edition of the Complete Psychological Works of Sigmund Freud (Vol. VII). Rio de Janeiro: Imago.

Freud, S. (1996d). On the History of the Psycho-Analytic Movement, Papers on Meta-psychology and Other Works (1915). In: The Standard Edition of the Complete Psychological Works of Sigmund Freud (Vol. VII). Rio de Janeiro: Imago.

Green, A. (1994). The Unbinding: Psychoanalysis, Anthropology and Literature. Rio de Janeiro: Imago.

Gagnebin, M. (1994). For a Psychoanalytical Aesthetics: The Artist, Strategy of the Unconscious. Paris: PUF.

Kris, E. (2000). Psychoanalytic Explorations in Art. Madison: International Universities Press.

Leclaire, S. (2007). To Psychoanalyze. São Paulo: Perspectiva.

Lacan, J. (1998). The Seminar of Jacques Lacan, Book 11: The Four Fundamental Concepts of Psychoanalysis. Rio de Janeiro: Jorge Zahar. 
Scientific Research Publishing (SCIRP) is one of the largest Open Access journal publishers. It is currently publishing more than 200 open access, online, peer-reviewed journals covering a wide range of academic disciplines. SCIRP serves the worldwide academic communities and contributes to the progress and application of science with its publication.

Other selected journals from SCIRP are listed as below. Submit your manuscript to us via either submit@scirp.org or Online Submission Portal.
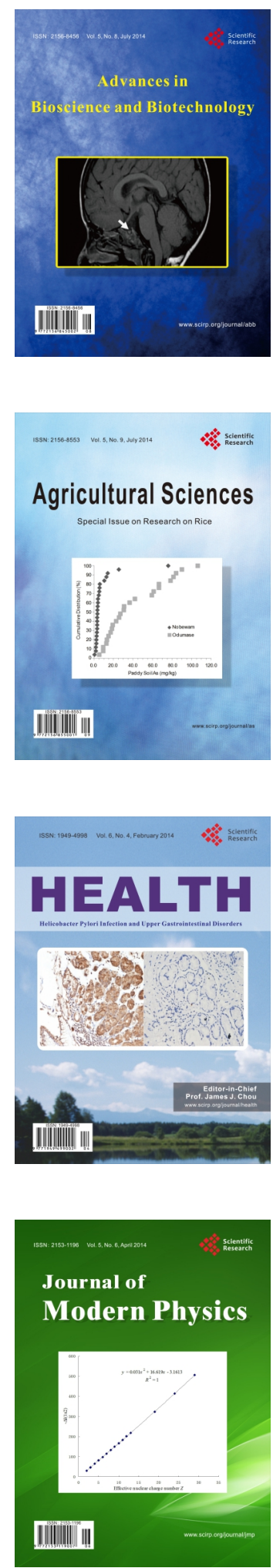
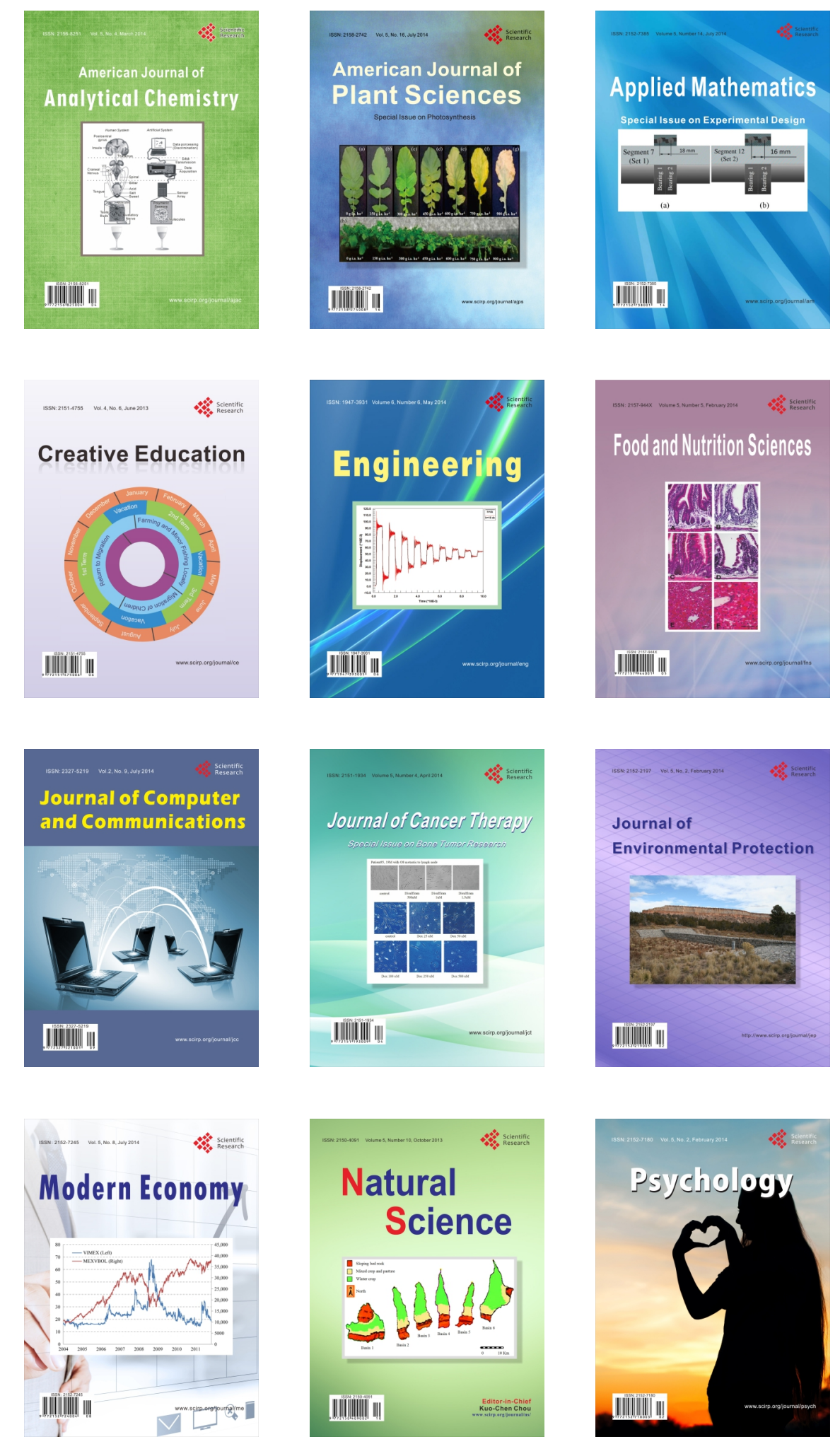